\title{
Interlanguage pragmatics and instructional pragmatics: two vibrant and illuminating research fields
}

Full Professor at School of Humanities (Letters) and of the Graduate Program in Letters at Pontifica Catholic University of Rio Grande do Sul, Brazil. https://orcid.org/0000-0002-9638-1180. E-mail: cperna@pucrs.br

2 Associate Professor at the Department of English Filology at University of Sevilla, Spain.

E-mail: mpadillacruz@us.es.

Doctoral student at Graduate Program in Letters at Pontifical Catholic University of Rio Grande do Sul, Brazi

https

E-mail: gisellerevisora@gmail.com.

Recebido em: 05/11/2019. Aprovado em: 05/11/2019.

Publicado em: 27/12/2019.

\section{Endereço:}

Cristina Lopes Perna

Partenon

Porto Alegre-RS

90619-900

Manuel Padilla Cruz

Sevilla, Espanha

Giselle Liana Fetter

mong the offspring of the broad discipline of pragmatics are interlanguage pragmatics and instructional pragmatics. A Inspired by the massive cross-cultural research undertaken in the late eighties and the beginning of the nineties, and pioneered by well-known figures such as Gabriele Kasper, Shoshana Blum-Kulka or Juliane House, to name but some, the former is traditionally defined as the study of learners' acquisition, development and operationalization of their L2 knowledge (KASPER, ROSE, 2001). Ever since its inception, this most fruitful strand of pragmatics has been inextricably connected with second language acquisition, so research therein has centred on L2 learners' communicative abilities, the problems that they face in certain circumstances and their failures and successes when using their target language(s) with a variety of purposes (KASPER, BLUM-KULKA, 1993; KASPER, SCHMIDT, 1996). Informed by diverse theoretical frameworks and approaches (KASPER, 2001), and relying on distinct empirical methods, practitioners in this field have dedicated their efforts to exploring a vast number of issues related to verbal production with a view to understanding what learners actually say when doing specific things with particular interlocutors in certain settings (BARDOVI-HARLIG, 2013). 
If there is an area that has attracted the attention of interlanguage pragmatists, it has almost certainly been learners' accomplishment of verbal actions in real or simulated situations. As a result, there is a wealth of studies on speech acts like greetings (JAWORSKI, 1994), apologies (OLSHTAIN, 1983; BLUM-KULKA, LEVENTSON, 1987; PERNA, 2002), requests (BLUM-KULKA, LEVENTSON, 1987; BLUM-KULKA, 1988; FæRCH, KASPER, 1989) or the expression of gratitude (HARLOW, 1990; EISENSTEIN, BODMAN, 1993). However, many other related communicative phenomena and idiosyncrasies of learners' communicative behaviour in their respective L2s have not been overlooked by practitioners in the field. Suffice to mention pragmatic failure (THOMAS, 1983; BEEBE, TAKAHASHI, 1989), pragmatic transfer (KASPER, 1992), (im)politeness and relational work (HINKEL, 1996; LoCASTRO, 1997), conversational management (KÖNIG, 2013; SHIVELY, 2015), or the use of pragmatic or discourse markers (ROMERO TRILLO,2002; GÁNEM-GUTIÉRREZ, ROEHR, 2011). In contrast, the works addressing L2 comprehension are less numerous, although not for this reason are they less illuminating or helpful. Some noteworthy examples are the studies on the effects of discourse markers on learners' understanding (CHAUDRON, RICHARDS, 1986), the problems that they have in deducing implicit contents (TAGUCHI, 2009, 2013) or in coping with idioms (COOPER, 2012), their perceptions of speech-act behaviour (WOODFIELD, 2012) or pragmatic violations (BARDOVI-HARLIG, DÖRNYEI, 2012), and their epistemic vigilance abilities (PADILLA CRUZ, 2013; IFANTIDOU, 2014).

Even if with a relatively shorter history, instructional pragmatics originated as an unavoidable offshoot or consequence of interlanguage pragmatics. The assumption underlying, and perhaps motivating, its creation seemed to be that, if L2 learners indisputably experience difficulties when putting in practice their L2 abstract knowledge and communicative skills, their performance may certainly benefit from instruction (ISHIHARA, COHEN, 2010). Therefore, the link between these two strands of pragmatics appears obvious: interlanguage pragmatics informs instructional pragmatics about learners' problems when using and processing the $\mathrm{L} 2$, as well as about the difficulties that some specific areas may pose to them, and the latter develops and provides tools to improve L2 learners' metapragmatic awareness and performance. As a result, instructional pragmatics may be portrayed as a branch of pragmatics concerned with the implementation of pedagogical procedures aimed at undertaking or improving the teaching of specific L2 pragmatic aspects (ISHIHARA, 2010; LOUW, DERWING, ABBOTT, 2010; ABRAMS, 2014). Its scope, however, cannot simply be limited to that valuable endeavour, as scholars have also addressed issues such as how the L2 pragmatics can be taught, the effects of diverse interventions such as explicit and implicit teaching, the benefits and drawbacks of deductive and inductive pedagogical treatments, the impact of study-abroad experiences or teacher training (ALCÓN SOLER, 2005; SAFONT JORDÁ, 2005; TAKAHASHI, 2005; ISHIHARA, 2010; TAGUCHI, 2015).

These two fields could not escape the attention of Letrônica, which devotes the current special issue to them. Under the overarching theme "Interlanguage and instructional pragmatics", it purports to show their vibrancy and present some of the recent interests, concerns and works done in each. It gathers seven contributions with distinct scopes by researchers from different universities. These contributions are arranged following precisely the order in which the two areas in focus are named in the title of the issue. Thus, the papers are divided into two groups. The first includes four papers dedicated to interlanguage pragmatics, while the second comprises the remaining three, which fall within the field of instructional pragmatics.

The first paper in the first group is by Giovani Santos and is entitled "Second language pragmatics: a corpus-based study of the pragmatic marker like". It addresses the use of this pragmatic marker by Brazilian university students living in Ireland and compares its interpersonal functions and procedural meanings to those of the marker as used by native speakers of Irish English. The second paper, "Ordens e pedidos em língua italiana: um estudo da percepção de falantes nativos e aprendizes brasileiros", is jointly authored by Luciane Nascimento Spadotto and Elisabetta Santoro. Focusing on learners' perceptions, it delves into the characteristics of orders and requests in Italian, and examines the criteria upon which native speakers and Brazilian learners of Italian differentiate them. "O inglês para aviação e a pragmática: uma proposta de investigação descritiva por meio da Linguística de Corpus" is the third paper in this group. Relying on corpus pragmatics, Malila Carvalho de Almeida Prado seeks to elucidate some important communicative elements employed by aviation professionals and the reasons underlying their choices in order to make future professionals aware of them. Finally, the fourth paper is "Mobile instant messaging: a bonanza for interlanguage pragmatics" and 
is contributed by Bethany Aull. After tracing the current state of research on this type of communication, the author argues that it may be interesting and helpful to interlanguage pragmatics research because of what it may reveal about the intersection of cultures and electronically-mediated communities.

As regards the second group, its first paper makes a pedagogical proposal. Authored by Manuel Padilla Cruz, "Dealing with jokes in the ESL class: A pedagogical proposal centred on comprehension" suggests five steps for working with English jokes in the ESL classroom and sensitizing learners to the elements on which their humorousness is contingent. The second and third papers, in contrast, turn attention to the assessment of the impact of pragmatic instruction. In "Investigating the effects of pragmatic instruction: A comparison of L2 Spanish compliments and apologies during short term study-abroad", Megan DiBartolomeo, Vanessa Elias and Daniel Jung analyze the development of those two expressive speech acts in students who completed a five-week studyabroad program in Mérida, Mexico, but only received instruction on the first of those speech acts. Similarly, Pauline Madella and Jesús Romero-Trillo examine the effect of instruction in "Prosodic pointing in inferential comprehension: the application of Relevance Theory to L2 listening instruction". This paper shows that introducing what the authors label prosodic pointing -which is defined as an ostensive phenomenon that includes both vocal and visual paralinguistic features, and is used synchronously to communicate intentions - to Chinese L2 learners can help them to fine-tune their epistemic vigilance in L2 English.

Certainly, the analyses presented in some of the papers gathered here may illuminate additional inquiries and provide valuable data for comparison and study of further issues. We hope that the considerations that other papers expound, and/or the issues that they raise, spark off further research in either of these two vibrant areas of pragmatics. Also, we hope that the pedagogical proposals offered by others inspire new ones that facilitate the teaching of L2 pragmatic issues or result in significant improvements of already existing ones. That future work will surely benefit the acquisition and teaching of second languages.

\section{References}

ABRAMS, Zsuzsanna I. Using film to provide a context for teaching L2 pragmatics. System, v. 46, p. 55-64, Oct. 2014. https://doi.org/10.1016/j.system.2014.06.005

ALCÓN SOLER, Eva. Does instruction work for learning pragmatics in the EFL context? System, V. 33, n 3, p. 417-435, Sep. 2005. https://doi.org/10.1016/j.system.2005.06.005

BARDOVI-HARLIG, Kathleen. Developing L2 pragmatics. Language Learning, v. 63, n 1, p. 68-86, Feb. 2013. https://doi.org/10.1111/j.1467-9922.2012.00738.x

BARDOVI-HARLIG, Kathleen; DÖRNYEI, Zoltán. Do language learners recognize pragmatic violations? Pragmatic versus grammatical awareness in instructed L2 learning. TESOL Quarterly, v. 32, n 2, p. 233-259, Jan. 2012. https://doi.org/10.2307/3587583

BEEBE, Leslie M.; TAKAHASHI, Tomoko. Do you have the bag?: Social status and patterned variation in second language acquisition. In: GASS, Susan; MADDEN, Carolyn; PRESTON, Dennis; SELINKER, Larry (eds.). Variation in Second Language Acquisition Clevedon: Multilingual Matters, 1989. p. 103-125. (Vol. 1: Discourse and pragmatics). https://doi.org/10.1017/s0272263100009591

BLUM-KULKA, Shoshana. Interpreting and performing speech acts in a second language: A cross-cultural study of Hebrew and English. In: WOLFSON, Nessa; JUDD, Elliot (eds.) Sociolinguistics and Language Acquisition. Rowley: Newbury House, 1988. p. 36-55. https:// doi.org/10.1017/s0047404500011672

BLUM-KULKA, Shoshana; LEVENSTON, Edward A. Lexical-grammatical pragmatic indicators. Studies in Second Language Acquisition, v. 9, n 2, p. 155-170, Jun. 1987. https://doi.org/10.1017/ $\underline{\mathbf{s} 0272263100000450}$

CHAUDRON, Craig; RICHARDS, Jack C. The effect of discourse markers on the comprehension of lectures. Applied Linguistics, v. 7, n 2, p. 113-127, Jul. 1986. https://doi.org/10.1093/applin/7.2.113

COOPER, Thomas C. Processing of idioms by L2 learners of English. TESOL Quarterly, v. 33, n 2, p. 233-262, Jan. 2012. https://doi.org/10.2307/3587719

EISENSTEIN, Miriam; BODMAN, Jean. Expressing gratitude in American English. In: KASPER, Gabriele; BLUM-KULKA, Shoshana (eds.). Interlanguage Pragmatics. New York: Oxford University Press, 1993. p. 64-81. https://doi.org/10.1017/s0047404500018649 
Færch, Claus; KASPER, Gabriele. Internal and external modification in interlanguage request realisation. In: HOUSE, Juliane; BLUM-KULKA, Shoshana; KASPER, Gabriele (eds.). Crosscultural Pragmatics: Requests and Apologies. Norwood: Ablex, 1989. p. 221-247. https://doi. org/10.1017/s0272263100010846

GÁNEM-GUTIÉRREZ, Gabriela A.; ROEHR, Karen. Use of L1, metalanguage, and discourse markers: L2 learners' regulation during individual task performance. International Journal of Applied Linguistics, v. 21, n 3, p. 397-318, Nov. 2011. https://doi.org/10.1111/i.1473-4192.2010.00274.x

HARLOW, Linda L. Do they mean what they say? Sociopragmatics competence and second language learners. The Modern Language Journal, v. 74, n 3, p. 328-351, 1990. https://doi. org/10.1111/j.1540-4781.1990.tb01070.x

HINKEL, Eli. When in Rome: Evaluations of L2 pragmalinguistic behaviors. Journal of Pragmatics, v. 26, n 1, p. 51-70, Jul. 1996. https://doi.org/10.1016/0378-2166(95)00043-7

IFANTIDOU, Elly. Pragmatic Competence and Relevance. Amsterdam: John Benjamins, 2014.

ISHIHARA, Noriko. Instructional pragmatics: Bridging teaching, research, and teacher education. Language and Linguistics Compass, v. 4, n 10, p. 938-953, Oct. 2010. https://doi. org/10.1111/j.1749-818x.2010.00242.x

ISHIHARA, Noriko; COHEN, Andrew D. Teaching and Learning Pragmatics. Where Language and Culture Meet. Harlow: Pearson Education, 2010. https://doi.org/10.1111/j.1540-4781.2012.01348.x

JAWORSKI, Adam. Pragmatic failure in a second language: Greeting responses in English by Polish students. International Review of Applied Linguistics in Language Teaching, v. 32, n 1, p. 41-55, 1994. https://doi.org/10.1515/iral.1994.32.1.41

KASPER, Gabriele. Pragmatic transfer. Second Language Research, v. 8, n 3, p. 203-231, Oct. 1992.

KASPER, Gabriele. Four perspectives on L2 pragmatic development. Applied Linguistics, v. 22, n 4, p. 502-530, Dec. 2001. https://doi.org/10.1093/applin/22.4.502

KASPER, Gabriele; BLUM-KULKA, Shoshana. Interlanguage Pragmatics: An Introduction. New York: Oxford University Press, 1993. https://doi.org/10.1017/s0047404500018649

KASPER, Gabriele; ROSE, Kenneth R. (eds.). Pragmatics in Language Teaching. Cambridge: Cambridge University Press, 2001.

KASPER, Gabriele; SCHMIDT, Richard. Developmental issues in interlanguage pragmatics. Studies in Second Language Acquisition, v. 18, n 2, p. 149-169, Jun. 1996 https://doi.org/10.1017/ $\underline{\mathbf{s} 0272263100014868}$
KÖNIG, Clelia. Topic management in French L2: A longitudinal conversation analytic study. EUROSLA Yearbook, v. 13, n 1, p. 226-250, Jan. 2013. https://doi.org/10.1075/eurosla.13.11kon

LoCASTRO, Virginia. Politeness and pragmatic competence in foreign language education. Language Teaching Research, v. 1, n 3, p. 239-267, Sep. 1997. https://doi. org/10.1177/13621688970010030

LOUW, Kerry J.; DERWING, Tracey M.; ABBOTT, Marilyn L. Teaching pragmatics to L2 learners for the workplace: The job interview. The Canadian Modern Language Review, v. 66, n 5, p. 739-758, Aug. 2010. https://doi.org/10.3138/cmlr.66.5.739

OLSHTAIN, Olite. Sociocultural competence and language transfer: The case of apology. In KRASHEN, Stephen D.; SCARCELLA, Robin (eds.). Series on Issues on Second Language Research Rowley: Newbury House, 1983. p. 232-249.

PADILLA CRUZ, Manuel. Metapsychological awareness of comprehension and epistemic vigilance of L2 communication in interlanguage pragmatic development. Journal of Pragmatics, v. 59, n A, p. 117-135, Dec. 2013. https://doi.org/10.1016/i.pragma.2013.09.005

PERNA, Cristina Lopes. A competência pragmática na realização de pedidos de desculpas em inglês como L2. In: IBAÑOS, A; SILVEIRA, J. (eds.). Na Interface Semântica/Pragmática. Porto Alegre: Edipucrs, 2002

ROMERO TRILLO, Jesús. The pragmatic fossilization of discourse markers in non-native speakers of English. Journal of Pragmatics, v. 34, n 6, p. 769-784, Jun. 2002. https://doi.org/10.1016/ s0378-2166(02)00022-x

SAFONT JORDÁ, María Pilar. Third Language Learners. Pragmatic Production and Awareness. Clevedon: Multilingual Matters, 2005.

SHIVELY, Rachel L. Developing interactional competence during study abroad: Listener responses in L2 Spanish. System, v. 48, p. 86-98, Feb. 2015. https://doi.org/10.1016/j.system.2014.09.007

TAGUCHI, Naoko. Corpus-informed assessment of comprehension of conversationa implicatures in L2 English. TESOL Quarterly, v. 43, n 4, p. 738-749, Dec. 2009. https://doi. org/10.1002/j.1545-7249.2009.tbo0202.x

TAGUCHI, Naoko. Comprehension of conversational implicature. What response times tell us In: TAGUCHI, Naoko; SYKES, Julie M. (eds.). Technology in Interlanguage Pragmatics Research and Teaching. Amsterdam: John Benjamins, 2013. p. 19-41. https://doi.org/10.1075/lllt.36.03tag 
TAGUCHI, Naoko. Instructed pragmatics at a glance: Where instructional studies were, are, and should be going. Language Teaching, v. 48, n 1, p. 1-50, Jan. 2015. https://doi.org/10.1017/ $\underline{\text { s0261444814000263 }}$

TAKAHASHI, Satomi. Noticing in task performance and learning outcomes: A qualitative analysis of instructional effects in interlanguage pragmatics. System, v. 33, n. 3, p. 437-431, Sept. 2005. https://doi.org/10.1016/j.system.2005.06.006

THOMAS, Jenny. Cross-cultural pragmatic failure. Applied Linguistics, v. 4, n 2, p. 91-112, 1983.

WOODFIELD, Helen. Pragmatic variation in learner perception. The role of retrospective verbal report in L2 speech act research. In: FÉLIX-BRASDEFER, Julio C.; KOIKE, Dale A. (eds.). Pragmatic Variation in First and Second Language Contexts: Methodological Issues. Amsterdam: John Benjamins, 2012. p. 209-237. https://doi.org/10.1075/impact.31.08woo 